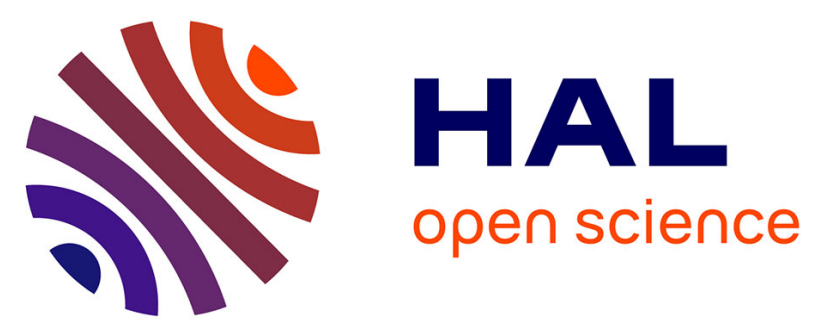

\title{
Establishing the provenance of the Nazareth Inscription: Using stable isotopes to resolve a historic controversy and trace ancient marble production
}

Kyle Harper, Michael Mccormick, Matthew Hamilton, Chantal Peiffert, Raymond Michels, Michael Engel

\section{To cite this version:}

Kyle Harper, Michael Mccormick, Matthew Hamilton, Chantal Peiffert, Raymond Michels, et al.. Establishing the provenance of the Nazareth Inscription: Using stable isotopes to resolve a historic controversy and trace ancient marble production. Journal of Archaeological Science: Reports, 2020, 30, pp.102228. 10.1016/j.jasrep.2020.102228 . hal-02934970

\section{HAL Id: hal-02934970 \\ https://hal.univ-lorraine.fr/hal-02934970}

Submitted on 10 Sep 2020

HAL is a multi-disciplinary open access archive for the deposit and dissemination of scientific research documents, whether they are published or not. The documents may come from teaching and research institutions in France or abroad, or from public or private research centers.
L'archive ouverte pluridisciplinaire HAL, est destinée au dépôt et à la diffusion de documents scientifiques de niveau recherche, publiés ou non, émanant des établissements d'enseignement et de recherche français ou étrangers, des laboratoires publics ou privés. 


\section{Establishing the provenance of the Nazareth Inscription: Using stable}

\section{isotopes to resolve a historic controversy and trace ancient marble production}

Kyle Harper ${ }^{\mathrm{a}}, *$, Michael McCormick ${ }^{\mathrm{b}}$, Matthew Hamilton ${ }^{\mathrm{c}}$, Chantal Peiffert ${ }^{\mathrm{d}}$, Raymond Michels ${ }^{\mathrm{d}}$, Michael Engel ${ }^{\mathrm{c}}$

${ }^{a}$ Department of Classics and Letters, University of Oklahoma, Norman, OK 73019, United States

${ }^{\mathrm{b}}$ Initiative for the Science of the Human Past, Department of History, Harvard University, Cambridge, MA 02138, United States

${ }^{c}$ School of Geosciences, University of Oklahoma, Norman, OK 73019, United States

${ }^{\mathrm{d}}$ GeoRessources Laboratory, Université de Lorraine, CNRS, CREGU, F-54506 Vandoeuvrelès-Nancy, France

Keywords: Nazareth Inscription, Marble Provenance, Stable Isotopes

\section{A B S T R A C T}

Stable oxygen and carbon isotope analyses are commonly used to attempt to establish the provenance of ancient marble artifacts such as statues and architectural elements. In this study we apply the technique for a novel purpose: establishing the provenance of an important and mysterious inscribed document from the Roman Empire known as the Nazareth Inscription. The stable isotope enrichment in ${ }^{13} \mathrm{C}$ and substantial depletion in ${ }^{18} \mathrm{O}$ provide a unique signature allowing the confident and unexpected identification of the upper quarry of the Greek island of Kos as the source of the marble. This information resolves a near century of debate among ancient historians about the significance of the inscription, hitherto most often connected with Roman reactions to early Christian reports of Jesus' empty tomb. It is proposed that the edict was issued by Caesar Augustus in response to the desecration of the grave of a famous tyrant from Kos named Nikias, a theory which more logically fits with the provenance of the marble and the events of that time. Isotope analyses of dated and localized inscriptions will deliver vast new data for the high resolution economic history of marble production and distribution around the ancient Mediterranean.

\section{Introduction}

This study uses stable isotope analysis for a novel application: exploring the provenance of the marble used for one of the most mysterious and potentially important epigraphic documents to survive from classical antiquity, the so-called Nazareth Inscription. Written in Greek on a slab of marble $60 \mathrm{~cm}$ tall, $37.5 \mathrm{~cm}$ wide, and $6 \mathrm{~cm}$ deep, the inscription records the text of an edict issued by a Roman ruler identified only as "Caesar" (Robert, 1936). The edict demands that tombs and graves remain undisturbed and that corpses not be destroyed or thrown out (Cumont, 1930). The edict classifies corpse removal and tomb disturbance as capital offenses. The text was first published in 1930, five years after the death of its long-time owner, Wilhelm Froehner. 
Froehner was an enigmatic German-born collector who moved in Parisian circles for over half a century (Hellmann, 1992; Harper, 2018). Froehner acquired the marble in 1878 in Paris and secluded it in his private collection until his death. His exiguous notes indicate that it was "sent from Nazareth" (Robert, 1936). Today, the artifact is held in the collection of the Département des Monnaies, Médailles et Antiques of the Bibliothèque nationale de France. Like many artifacts in western collections, the Nazareth Inscription was acquired before modern standards of archaeology and museum accessioning were established, and hence, the true provenance of the Nazareth Inscription, and its route to Froehner in Paris in 1878, are unknown. This uncertainty has complicated the study of the document.

A number of hypotheses have been proposed to account for the inscription's original context and purpose (reviewed in Tsalampouni, 2001). The content of the edict and the style of the lettering suggest a date sometime between the later first century $\mathrm{BC}$ and the first century $\mathrm{CE}$, the formative period of Roman imperialism in the eastern Mediterranean.

One hypothesis holds that the inscription originated in the Levant (whether in Nazareth or, as seems more likely, a nearby town like Sepphoris or Tiberias) and represents the Roman Emperor's reaction to the controversy stirred by claims of Christ's resurrection from the tomb (Gruyzbek and Sordi, 1998). As the Gospel of Matthew (see Matthew 28:16) and other early texts make clear, the question aroused intense polemics in Palestine and beyond, already during the career of the apostle Paul (fl. 30-64 CE, e.g. First Corinthians 1:23). Nazareth was a relatively obscure village in the Galilee, notable for little in Roman times other than being the hometown of Jesus (Tzaferis and Bagatti, 1993). If the purpose of the edict was somehow a reaction to the early Christian movement, then this document stands as the oldest physical artifact connected to the new religion and among the most important inscriptions from the ancient world.

A competing interpretation argues that the inscription has nothing to do with Christianity, nor even the Levant (Giovannini and Hirt, 1999). In this hypothesis, the provenance of the inscription was Asia Minor, rather than Palestine. Froehner, or some other buyer along the way, was misled into believing that the stone had some connection to Nazareth, perhaps by a seller hoping to enhance the market value of the artifact. One study maintains that the Nazareth Inscription should be seen as part of the efforts of the first Roman Emperor, Augustus (adopted son of Julius Caesar and founder of the Julio-Claudian dynasty of emperors), to bring order to Asia after the period of civil war that had characterized much of the preceding generation (Giovannini and Hirt,1999). Its argument depends heavily on the observation that the Greek word used for tomb-robbery is rare outside the inscriptions of Asia Minor (of 177 examples they found, only two come from other regions). But the evidence is inconclusive, especially given the relative paucity of comparable contemporaneous inscriptions from other parts of the empire, including Palestine.

The matter remains unsettled and has reached an impasse. We have used geochemical analysis to trace the provenance of the stone and clarify this particular question. At the same time, this study takes a first step in developing the potentially massive evidence of surviving ancient inscriptions whose texts bear an explicit date or datable reference as precise geochemical tracers of stone movement. Localizing the quarries that supplied the stone for Greek and Latin inscriptions would illuminate how the supply, demand, and distribution patterns of one of the most widely traded ancient raw materials changed over time. The pinpoint chronology of many 
inscriptions, bearing the date when they were engraved, would also shed bright new light on the ever vexed question of the precise chronology of extraction of specific quarries, a process which by its very nature removes most evidence about the timing of extraction (Ward-Perkins, 1980; Lazzarini, 2004; Russell, 2013). Establishing a precise chronology of extraction would, in turn, allow more exact, scientifically-grounded dates of the countless sculptures and buildings that incorporate the extracted marbles but lack explicit dates (Herz and Waelkens, 1988).

Marbles consist of carbonate minerals, most commonly calcite $(\mathrm{CaCO} 3)$ and to a lesser extent dolomite $(\mathrm{CaMg}(\mathrm{CO} 3) 2)$. There have been numerous studies concerning the stable carbon and oxygen isotope compositions of marbles, many of which have been shown to have distinct isotopic signatures resulting from their parent rock compositions and metamorphic histories (e.g., Craig and Craig, 1972; Lapuente et al., 2000; Lazzarini and Antonelli, 2003; Attanasio et al., 2006; Attanasio et al., 2008; Lazzarini and Malacrino, 2010; Antonelli and Lazzarini, 2015). A common geochemical approach that has been used to establish the provenance of archaeological marble artifacts has been to compare their respective stable carbon and oxygen isotope compositions to those of marbles from quarries from throughout the Mediterranean region (e.g. Craig and Craig, 1972; Lapuente et al., 2000; Antonelli et al., 2014; Al-Bashaireh and Bedal, 2017). But to the best of our knowledge, previous studies have not used stable isotope analysis to identify the quarry of an important inscription whose provenance was unknown.

The Bibliothèque nationale de France granted the authors permission to obtain minute samples from the back of the Nazareth Inscription (Fig. 2). As will be discussed below, its distinctive isotopic signature enabled us to establish a likely source for this marble tablet and to provide a novel hypothesis for the precise context for the origins of the imperial edict.

\section{Materials and methods}

\subsection{The Nazareth Inscription}

In twenty-two lines of Greek, the text of the Nazareth Inscription presents an edict of an unnamed Roman emperor imposing severe punishment for the disturbance of tombs and corpses. The inscription reads: "Edict of Caesar. It is my pleasure that graves and tombs which anyone has prepared as a pious service for forebears, children, or members of his household are to remain forever unmolested. But if any person shows that another either has destroyed them, or in any other way has cast forth the persons buried there, or with malicious deception has transferred the bodies elsewhere to the dishonor of the dead, or has removed the inscribed or other stones, I command an action to be instituted against such person, protecting the pious services of men, just as if they were concerned with the gods. For it shall be by far more proper to do honor to the dead. No one whatsoever shall be permitted to remove them. If anyone does so, however, it is my will that he shall suffer capital punishment on the charge of desecration of graves." (translated by Pharr, 1961; Greek original in supplement).

The law presented in the text was unambiguously an imperial edict (= $\delta$ ió $\tau \alpha \gamma \mu \alpha$ in Greek: Mason, 1974). In contrast to rescripts, by which the emperor responded to individuals in private cases, edicts were public enactments with general force. The text bears obvious signs of having been translated from Latin into Greek, with a number of phrases drawn from commonplace 
expressions or technical language in Roman law (for example, "It is my pleasure" = mihi placet; "malicious deception" = dolo malo). The text of the edict divides into two parts. The first uses the past tense and concerns acts of desecration that have already occurred; these were to be punished as crimes of a public nature, assimilated to offenses against the gods (Giovannini and Hirt, 1999). In the second part of the text, the future tense refers to any further acts of tomb violation and unambiguously threatens capital punishment for the profanation of tombs.

In the ancient world, the violation or robbery of tombs was a major concern for both private individuals and public authorities (Metzger, 1980). Often, curses were used to deter those who might desecrate a burial site. At some point in the Roman Empire, the violation of a tomb became a public crime, probably with the very edict represented in the Nazareth Inscription (Rebillard, 2009). At present there is no consensus as to the impetus behind the edict's enactment, and opinion has remained divided between the two alternatives already proposed by the very first editor of the text, Franz Cumont (1930). He suggested that the law could have been part of the general restoration of religion, morals, and social order by the first emperor, Augustus, but he also allowed that the edict might reflect the controversy prompted by early Christian claims of the resurrection. The latter interpretation would be bolstered if the inscription had genuine connections with Galilee, as suggested by Froehner's exiguous note attributing the stone's origins to Nazareth. Our geochemical analysis, however, supports the first hypothesis and provides a new and precise context for the imperial enactment.

\subsection{Sample collection}

Sampling of the Nazareth Inscription (Fig. 1) was conducted by Dr. Raymond Michels (CNRS) under the supervision of Dr. Mathilde Avisseau-Broustet, Conservateur en chef au département des Monnaies, médailles et antiques, Bibliothèque nationale de France. A surface of approximately $2 \mathrm{~cm}^{2}$ was first mildly abraded with a dental drill bit mounted on a variable speed rotary drill to remove the surface. The freshly exposed white marble layer (Fig. 2) was then mildly abraded with the dental drill to collect two samples of marble powder, which were subsequently transferred to clean glass vials. Each sample consisted of approximately 5-10 mg. A sample from one of the vials was analyzed for elemental composition by LA-ICP-MS at the Université de Lorraine, France. Replicate samples from the second vial were analyzed for their stable isotope compositions at the University of Oklahoma.

\subsection{Elemental analysis}

A $1 \mathrm{mg}$ sample of the Nazareth Inscription powder was analyzed byLA-ICP-MS (Lach et al., 2013; Bonnet et al., 2016). The analytical system is composed of a $193 \mathrm{~nm}$ MicroLas Pro ArF Excimer coupled with the Agilent 7500 quadrupole ICP-MS and was used to determine the carbonate mineral composition of the inscription. Laser ablations were performed at a $5 \mathrm{~Hz}$ pulse rate during $30 \mathrm{~s}$ and a constant fluence of $6 \mathrm{~J} / \mathrm{cm} 2$ by focusing the beam at the sample surface. The transport gas was a mixture of $\mathrm{He}$ and Ar, at typical flow rates of 0.5 and $0.9 \mathrm{~L} /$ min respectively. All data were acquired in raw counts using time resolved mode. The following isotopes were measured with a dwell time of $10 \mathrm{~ms}$ for each: $24 \mathrm{Mg}, 43 \mathrm{Ca}, 44 \mathrm{Ca}, 56 \mathrm{Fe}$ and 88Sr. The certified reference materials SRM NIST 610 and 612 glasses (Jochum et al., 2016) as well as pure dolomite ( $\mathrm{Ca}$ and $\mathrm{Mg}$ contents determined by electron microprobe) were used 
as external standards for calibration while the internal standard used was Ca. Data reduction was carried out using Iolite V3 software, following standard methods (Longerich et al., 1996).

The analytical precision is calculated for all analysed elements using standard deviation of recorded intensity and is better than $\pm 5 \%$. The limit of detection varies for each element and each analysis as a function of signal intensity and was calculated for each ablation from signal intensities using the $2 \sigma$ criterion. The elemental analysis (Ca: $440200 \pm 17000$ ppm; Mg: 6258 $\pm 162 \mathrm{ppm}$; Sr: $227 \pm 5 \mathrm{ppm}$ ) indicated that the carbonate mineral phase is calcite. This information was used to determine the experimental conditions and appropriate fractionation factors for the stable carbon and oxygen isotope analysis of the inscription discussed below.

\subsection{Stable carbon and oxygen isotope analysis}

Three samples of marble powder from the Nazareth Inscription ( 200-300 $\mu \mathrm{g}$ each) were loaded into separate glass reaction vials and sealed under an ultra-high purity helium atmosphere (99.999\%) using a ThermoGas Bench II system equipped with the PAL gas sampling system. Next, $0.4 \mathrm{~mL}$ of $100 \%$ phosphoric acid was injected through the rubber septa cap of each vial and the vials were heated at $50{ }^{\circ} \mathrm{C}$ for $2 \mathrm{~h}$.

The $\mathrm{CO}_{2}$ gas released from the marbles by acid digestion was analyzed for $\delta^{13} \mathrm{C}$ and $\delta^{18} \mathrm{O}$ using a Thermo Delta V Plus isotope ratio mass spectrometer. The stable carbon and oxygen isotopic compositions are expressed using the equations proposed by Coplen (2011). The $\delta^{13} \mathrm{C}$ values of the marble samples, consisting almost exclusively of calcite, are reported relative to VPDB on a scale normalized such that the $\delta^{13} \mathrm{C}$ of NBS18 is $-5.01 \%$ (per mil, Kim et al., 2015). The $\delta^{18}$ OVPDB values of the samples are reported on a scale normalized such that the $\delta^{18} \mathrm{O}$ of SLAP is $-55.5 \%$ relative to VSMOW. On this $\delta^{18}$ OVPDB scale, the values of NBS 18 and NBS 19 are $-23.01 \%$ and $-2.2 \%$, respectively (Brand et al.,2014).

The oxygen isotope acid fractionation factor of calcite digested at $50{ }^{\circ} \mathrm{C}$ is 1.00934 (Kim et al., 2015). The calcite $\delta^{18}$ OVSMOW- SLAP values were converted to the $\delta^{18}$ OVPDB values by using the IUPAC-recommended equation, $\delta^{18}$ OVSMOW-SLAP $=1.03092 \delta^{18}$ OVPDB + 30.92\%o (Kim et al., 2015).

\section{Results}

Triplicate stable isotope analyses of the Nazareth Inscription marbles (Table 1) had mean values and standard errors of $5.2 \pm 0.1 \%$ (standard deviation $0.2 \%$ ) for carbon and $-10.5 \pm 0.3 \%$ (standard deviation $0.5 \%$ ) for oxygen. Of the hundreds of marbles and marble artifacts that have been analyzed from numerous locations in the Mediterranean, the Nazareth Inscription matches most closely a relatively unique isotopic signature previously reported by Lazzarini and Malacrino (2010) for white calcite marbles from the upper quarry on the Greek island of Kos, in the Dodecanese island chain located off the southwestern coast of Turkey. While substantial overlap is commonly observed for the ranges of stable carbon and oxygen isotope values of marbles from many of the major marble quarries of the Mediterranean region (e.g., Antonelli and Lazzarini, 2015), and some isotopic variability is not infrequently observed in individual quarries (e.g., Craig and Craig, 1972; Wenner et al., 1988; Attanasio et al., 2006; Antonelli and Lazzarini, 2015), the calcite-rich marbles from the upper quarry of Kos are 
substantially enriched in $13 \mathrm{C}$ and substantially depleted in ${ }^{18} \mathrm{O}$ (Lazzarini and Malacrino, 2010), a characteristic that is, to the best of our knowledge, unique among published isotopic values for white marbles from the central and eastern Mediterranean. The only other marble quarries in the Mediterranean region that have stable isotope compositions close to that of the quarry on Kos are Lubrin, in SE Spain (Lapuente et al., 2000) and Teos in Turkey (Attanasio et al., 2017).

However, the stable oxygen isotope composition of marbles from Lubrin are approximately $2 \%$ more depleted in 180 than Kos or the Nazareth Inscription. The marbles from Teos are dark marbles and thus do not match the color of the white marble of the Nazareth Inscription (Fig. 2). A comparison of what we believe to be most of the published stable carbon and oxygen isotope values for primarily white marbles from the Mediterranean region and the isotope values for the Nazareth Inscription is represented in Fig. 3A-D. Stable isotope values for marbles from Italy (Attanasio et al., 2006; Cavari et al., 2012; Franzini et al., 2010), Iberia (Lapuente et al., 2000; Morbidelli et al., 2007; Origlia et al., 2011) and North Africa (Antonelli et al., 2009; Origlia et al., 2012) are shown in Fig. 3A. Anatolian/Turkish Marbles (Capedri et al., 2004; De Paepe et al., 2004; De Paepe et al., 2006; Attanasio et al., 2006; Attanasio et al., 2008; Attanasio et al., 2009; Ramage and Tykot, 2011; Cahill and Lazzarini, 2014; Brilli et al., 2015; Sekedat, 2016) are shown in Fig. 3B. Greek and Greek Aegean Marbles (Lazzarini and Cancelliere, 2000; Capedri et al., 2004; Attanasio et al., 2006; Lazzarini and Malacrino, 2010) are shown in Fig. 3C. Fig. 3B and 3C are particularly striking, as they include isotope values from all of the common export marbles of the eastern Mediterranean, underscoring the likelihood of a match between the marble of the Nazareth Inscription and Kos. Fig. 3D zooms in to represent the literature values for the marbles closest to the Nazareth Inscription.

The stable carbon and oxygen isotopic variability of marbles generally reflects that of the limestones and/or dolomites from which they are derived (e.g. Wenner et al., 1988). Secular isotopic trends observed for parent (i.e. protolith) limestones (see, for example, Veizer et al., 1999; Sharp, 2017) should in theory be reflected in the isotopic compositions of their respective marbles, which in turn might also help to determine the provenance of marble artifacts. The geologic age reported for the Kos marbles is Paleozoic, possibly as early as the Ordovician (Lazzarini and Malacrino, 2010). The substantial depletion in ${ }^{18} \mathrm{O}$ matches an Ordovician age for this marble as carbonates tend to become more depleted in $18 \mathrm{O}$ with increasing geologic age (e.g., Veizer et al., 1999; Sharp, 2017). The stable oxygen isotope compositions of the Kos marbles and the Nazareth Inscription fall within the general range commonly reported for diagenetically altered limestones (Sharp, 2017). Although relatively pure calcite marbles are resistant to diagenetic alteration by contact with fluids (e.g. Rumble et al., 2000; Sharp, 2017), higher grade metamorphic events may alter the initial isotope composition of a marble (e.g. Rumble et al., 2000). Thus, establishing the geologic age for a marble based on its stable carbon and oxygen composition requires that the geologic history of the metamorphic event be wellconstrained.

\section{Discussion}

Assuming that the marble originated in the Mediterranean region, the stable isotope data presented above strongly indicate that the marble used for the Nazareth Inscription came from Kos. The quarries of Kos were an important source of marbles for major construction projects dating back to the second century BCE (Lazzarini and Malacrino, 2010; Poupaki, 2017). 
Further, a large number of inscriptions on marble survive from Kos itself during the period when the Nazareth Inscription was engraved, and archaeologists have identified the specific quarries that were active on Kos at this time (Poupaki, 2017), including the upper quarry. No one has heretofore suspected any connection between the Nazareth Inscription and the island of Kos. But the probability that the marble used to engrave this edict of Caesar originated on Kos has unexpected implications for various hypotheses concerning the context and purpose of the Nazareth Inscription. Consider the possibility that the putative Palestinian origin of the stone is correct. The Herodian dynasty that ruled Judea and parts of Palestine in the first centuries BCE and CE had well established connections with Kos. Herod the Great (who was King of Judea from 40 BCE to 4 BCE) endowed a gymnasium on Kos (Josephus, Bellum Judaicum 1.21.11), and several citizens of Kos were involved in the intrigues at his court (Josephus, Bellum Judaicum, 1.26.5). Remarkably, both Herod the Great and his son, Herod Antipas (who was the ruler of Galilee from $4 \mathrm{BCE}$ to $39 \mathrm{CE}$ ), are honored in contemporary inscriptions that survive on the island of Kos (Sherwin-White, 1978). The power of the Herodian dynasty depended upon distant Roman overlords, and the dynasty actively cultivated networks of alliance across the eastern Mediterranean to bolster their standing with leading Romans. The visibility of Herod the Great and Herod Antipas in Kos is due to these cultural and diplomatic efforts. It opens the intriguing possibility that the marble used in the Nazareth Inscription traveled to Palestine on commercial networks that mirrored political networks - indeed linking Kos and Galilee - which are also visible in the epigraphic and historical records.

At the same time, the origin of the marble on Kos strongly supports the conclusion that Froehner's informants misled him about the provenance of the stone. While any marble in Palestine must necessarily have been imported given the lack of local sources (Fischer, 1998; 2007), in fact the identification of Kos as a possible source of the stone furnishes a different and compelling context for the edict of Caesar. It has already been suggested by others that the inscription reflects the efforts of Augustus to settle the east after the series of civil wars that had followed the death of Julius Caesar. Indeed, it is now possible to propose a much more specific occasion for the inscription. During the 30s BCE, a period of uneasy alliance between Octavian Caesar (the future emperor Augustus) and Mark Antony, Kos was ruled by a tyrant named Nikias, a man of great local importance and broad connections, well known in Rome itself (Buraselis, 2000). Like many rulers in the east, Nikias was likely a partisan of Mark Antony and Cleopatra in their famous conflict against Octavian. Sometime after his death, for reasons that remain obscure, the people of Kos broke into the tomb of Nikias and desecrated his corpse. The affair was scandalous enough that a near contemporary Greek poet used the life of Nikias as a byword for the reversal of fortune: "Observe the fate of Nikias of Kos. Having already been laid to rest among the shades, his corpse was dragged out into the sunlight. For the people of the city pried open the bars of his tomb, and dragged out the wretch for the punishment of a second death" (Buraselis, 2000). A parsimonious explanation would be that the Edict of Caesar was issued by Augustus as a reaction to this unruly episode on Kos. In this case, Froehner and/or his buyers were duped by a clever merchant, and the violated tomb and removed corpse in question on the Nazareth Inscription are not those of Christ, but Nikias. Stable isotope analysis identifying the quarry of origin for the stone used in the famous Nazareth Inscription has provided new information that allows a novel - and unexpected - resolution of this nearly centurylong mystery. Occam's razor suggests that the Edict of Caesar was prompted by an episode of tomb desecration on the very island where the marble was quarried. The Nazareth Inscription should be seen not as a document of Rome's reaction to early Christianity. Rather, 
it reflects the efforts of the first emperor, Augustus, to establish law and order in the eastern Mediterranean in the years after he had defeated Antony and Cleopatra at the Battle of Actium.

At the same time, this study shows the potential of applying isotopic analysis, well developed already by specialists of ancient architecture, to the marble engraved with localized and precisely dated ancient inscriptions. Tracking the ebb and flow of imported marble on which local artisans carved dated and securely localized inscriptions that survived from classical civilization will vastly enrich the evidentiary base for the detailed reconstruction of the productive trajectory of specific quarries and of the aggregate economy which demanded their marbles.

\section{Conclusions}

Stable isotopes afford a powerful probe for determining the provenance of ancient marble antiquities. Our preliminary results indicate that marble from the upper quarry of the island of Kos is a likely source for the tablet of the Nazareth Inscription, although we cannot completely rule out additional marbles from the region of similar stable isotope compositions that have yet to be discovered and/or reported. The use of stable isotope analysis provides new information about the history of this important ancient document. Although studied for nearly a century, the stone's place of origin had never been suggested as Kos. This identification has allowed new and richer contexts for recovering the inscription's history and developing an original hypothesis concerning a local tyrant named Nikias, whose tomb was desecrated during the period in question. We believe that this novel application of geochemical analysis suggests the possibility of studying other inscriptions of unknown provenance using similar methods. No less importantly, applying this type of geochemical analysis to inscriptions of known provenance and date promises to deliver vast amounts of new information on the history of individual production centers and the shifting demand for their marbles around the ancient Mediterranean economy.

\section{Acknowledgements}

The authors would like to thank Franck Bellugeon (Bibliothèque Nationale de France) for guidance and help within Bibliothèque nationale de France. We are deeply grateful to Mathilde Avisseau-Broustet, Conservateur en chef au département des Monnaies, médailles et antiques,

Bibliothéque nationale de France, for permitting access to the Nazareth Inscription, to Cécile Morrisson for kind assistance throughout, and to the Initiative for the Science of the Human Past at Harvard University. We thank Rick Maynard for his assistance with the stable isotope analyses. We thank Christopher Jones for his expert advice on Greek epigraphy and comments on drafts of the study - and for his keynote at the 15th International Congress on Greek and Latin Epigraphy which provided the impetus for this study (Jones, 2019).

\section{References}

Al-Bashaireh, K., Bedal, L.-A., 2017. Provenance of white and colored marbles from the 
Petra garden and pool complex, Petra South Jordan. Archaeol. Anthropol. Sci. 9, 817-829. https://doi.org/10.1007/s12520-015-0305-9.

Antonelli, F., Lazzarini, L., Cancelliere, S., Dessandier, D., 2009. Minero-petrographic and geochemical characterization of 'greco scritto' marble from Cap de Garde near Hippo Regius (Annaba, Algeria). Archaeometry 51, 351-365. https://doi.org/10.1111/j. 1475-4754.2008.00408.x.

Antonelli, F., Columbu, S., Lezzerini, M., Miriello, D., 2014. Petrographic characterization and provenance determination of the white marbles used in the Roman sculptures of Forum Sempronii (Fossombrone, Marche, Italy). Appl. Phys. A 115, 1033-1040. https://doi.org/10.1007/s00339-013-7938-2.

Antonelli, F., Lazzarini, L., 2015. An updated petrographic and isotopic reference database for white marbles used in antiquity. Rend. Fis. Acc. Lincei 26, 399-413. https:// Attanasio, D., Brilli, M., Ogle, N., 2006. The Isotopic Signature of Classical Marbles. L'Erma di Bretschneider, Rome.

Attanasio, D., Brilli, M., Bruno, M., 2008. The properties and identification of marble from Proconnesos (Marmara Island, Turkey): A new database including isotopic, EPR and petrographic data. Archaeometry 50, 747-774. https://doi.org/10.1111/j.14754754.2007.00364.x.

Attanasio, D., Bruno, M., Yavuz, A.B., 2009. Quarries in the region of Aphrodisias: the black and white marbles of Göktepe (Muğla). J. Roman Archaeol. 22, 312-348. https://doi.org/10.1017/S1047759400020729. Attanasio, D., Bruno, M., Prochaska, W., Yavuz, A.B., 2017. Ancient 'black' decorative stones and the Ephesian origin of sculptural bigio antico. Archaeometry 59, 794-814. https://doi.org/10.1111/arcm.12278.

Bonnet, J., Mosser-Ruck, R., Caumon, M.-C., Rouer, O., André-Mayer, A.-S., Cauzid, J., Peiffert, C., 2016. Trace element distribution (Cu, Ga, Ge, Cd, and Fe) in sphalerite from the Tennessee MVT Deposits, USA, by combined EMPA, LA-ICP-MS, Raman spectroscopy, and crystallography. Can. Mineral. 54, 1261-1284. https://doi.org/10. 3749/canmin.1500104.

Brand, W.A., Coplen, T.B., Vogl, J., Rosner, M., Prohaska, T., 2014. Assessment of international 
reference materials for isotope-ratio analysis (IUPAC technical report).

Pure Appl. Chem. 86, 425-467. https://doi.org/10.1515/pac-2013-1023.

Brilli, M., Giustini, F., Conte, A.M., Mercadal, P.L., Quarta, G., Plumed, H.R., Scardozzi, G., Belardi, G., 2015. Petrography, geochemistry, and cathodoluminescence of ancient white marble from quarries in the southern Phrygia and northern Caria regions of Turkey: Considerations on provenance discrimination. J. Archaeol. Sci.: Rep. 4, 124-142. https://doi.org/10.1016/j.jasrep.2015.08.036.

Buraselis, K., 2000. Kos between Hellenism and Rome: studies on the political, institutional and social history of Kos from ca. the middle second century B.C. until late antiquity. Trans. Am. Philos. Soc. 90 (4), i-189.

Cahill, N., Lazzarini, L., 2014. The quarries of the Mağara Deresi and the marble of the Temple of Artemis at Sardis. Marmora 10, 27-44. https://doi.org/10.1400/238687.

Capedri, S., Venturelli, G., Photiades, A., 2004. Accessory minerals and $\delta 18 \mathrm{O}$ and $\delta 13 \mathrm{C}$ of marbles from the Mediterranean area. J. Cult. Heritage 5, 27-47. https://doi.org/10. 1016/j.culher.2003.03.003.

Cavari, F., Droghini, F., Giamello, M., Lazzarini, L., Mascione, C., 2012. The white marble quarries of Campiglia Marittima (Livorno, Italy) and the provenance of marble artefacts from Populonia. In: Gutierrez Garcia-Moreno, A. (Ed.), ASMOSIA IX Interdisciplinary Studies on Ancient Stone. Institut Catala d'Arqueologia Classica, pp. $390-400$.

Coplen, T.B., 2011. Guidelines and recommended terms for expression of stable-isotoperatio and gas-ratio measurement results. Rapid Commun. Mass Spectrom. 25, 2538-2560. https://doi.org/10.1002/rcm.5129.

Craig, H., Craig, V., 1972. Greek marbles: Determination of provenance by isotopic analysis. Science 176, 401-403. https://doi.org/10.1126/science.176.4033.401.

Cumont, F., 1930. Un rescrit impérial sur la violation de sépulture. Revue historique 163, $341-366$.

De Paepe, P., De Donder, J., De Dapper, M., Moens, L., 2004. Petrographic and stable isotope data for marbles from the neighbourhood of Tekören, Dínek and Atlas (Central Anatolia, Turkey). Anatolia Antiqua 12, 97-104. https://doi.org/10.3406/ 
anata.2004.1020.

De Paepe, P., De Donder, J., De Dapper, M., Moens, L., 2006. Stable isotope signatures of marbles from the Sivrihisar region (Central Anatolia, Turkey). Anatolia Antiqua 14, 131-141. https://doi.org/10.3406/anata.2006.1068.

Fischer, M., 1998. Marble Studies: Roman Palestine and the Marble Trade, Konstanz. Fischer, M., 2007. Marble imports and local counterparts: Luxury business in Roman Palestine. Topoi. Orient-Occident (suppl. 8), 249-269.

Franzini, M., Lezzerini, M., Origlia, F., 2010. Marbles from the Campiglia Marittima area (Tuscany, Italy). Eur. J. Mineral. 22, 881-893. https://doi.org/10.1127/0935-1221/ 2010/0022-2056.

Giovannini, A., Hirt, M., 1999. L'inscription de Nazareth: Nouvelle interprétation. Zeitschrift für Papyrologie und Epigraphik 124, 107-132. https://www.jstor.org/ stable/20190342.

Gruyzbek, E., Sordi, M., 1998. L'Édit de Nazareth et la politique de Néron à l'égard des chrétiens. Zeitschrift für Papyrologie und Epigraphik 120, 279-291. https://www. jstor.org/stable/20190172.

Harper, K., The emperor and the empty tomb: An ancient inscription, an eccentric scholar, and the human need to touch the past. Los Angeles Review of Books, 11 November 2018. Available at https://lareviewofbooks.org/article/the-emperor-and-the-emptytomban-ancient-inscription-an-eccentric-scholar-and-the-human-need-to-touch-thepast/, accessed 15 July 2019.

Hellmann, M.-C., 1992. "Wilhelm Froehner, un collectionneur pas comme les autres, 1834-1925.” In: K. Pomian, A.-F. Laurens (Eds.), L’anticomanie: la collection d'antiquités aux 18e et 19e siècles. Paris, pp. 251-64.

Herz, N., Waelkens, M. (Eds.), 1988. Classical Marble: Geochemistry, Technology, Trade. Dordrecht.

Jochum, K.P., Weis, U., Schwager, B., Stoll, B., Wilson, S.A., Haug, G.H., Andreae, M.O., Enzweiler, J., 2016. Reference values following ISO guidelines for frequently requested rock reference materials. Geostand. Geoanal. Res. 40, 33-350. https://doi. org/10.1111/j.1751-908X.2015.00392.X. 
Jones, C., 2019. Epigraphy between philology and technology, In: P. Amann, et al. (Ed.), Sprachen - Schriftkulturen - Identitäten der Antike. Vienna, 17-26.

Kim, S.-T., Coplen, T.B., Horita, J., 2015. Normalization of stable isotope data for carbonate minerals: Implementation of IUPAC guidelines. Geochimicha et Cosmochimica Acta 158, 276-289. https://doi.org/10.1016/j.gca.2015.02.011. Lach, P., Mercadier, J., Dubessy, J., Boiron, M.-C., Cuney, M., 2013. In situ quantitative measurement of rare earth elements in Uranium oxides by laser ablation-inductively coupled plasma-mass spectrometry. Geostand. Geoanal. Res. 37 (3), 277-296. https://doi.org/10.1111/j.1751-908X.2012.00161.x. Lapuente, M.P., Turi, B., Blanc, P., 2000. Marbles from Roman Hispania: Stable isotope and cathodoluminescence characterization. Appl. Geochem. 15, 1469-1493. https:// doi.org/10.1016/S0883-2927(00)00002-0.

Lazzarini, L., Cancelliere, S., 2000. Characterization of the white marble of two unpublished ancient Roman quarries on the islands of Fourni and Skyros (Greece).

Periodico di Mineralogia 69, 49-62.

Lazzarini, L., Antonelli, F., 2003. Petrographic and isotopic characterization of the marble of the island of Tinos Greece. Archaeometry 45, 541-552. https://doi.org/10.1046/j. 1475-4754.2003.00127.x.

Lazzarini, L. (Ed.), 2004. Pietre e marmi antichi. Natura, caratterizzazione, origine, storia d'uso, diffusione, collezionismo, Cedam.

Lazzarini, L., Malacrino, C.G., 2010. The white marble of Kos, its quarries and archaeometric characterization. Marmora 6, 57-70. https://doi.org/10.1400/171746.

Longerich, H.P., Jackson, S.E., Gunther, D., 1996. Laser ablation inductively coupled plasma mass spectrometric transient signal data. Acquisition and analyte concentration calculation. J. Anal. At. Spectrom. 11, 899-904. https://doi.org/10.1039/ JA9961100899.

Mason, H. 1974. Greek Terms for Roman Institutions: A Lexicon and Analysis, Toronto. Metzger, Bruce M., 1980. The Nazareth Inscription Once Again. In: Metzger, Bruce M. (Ed.), New Testament studies (philological, versional, and patristic). BRILL. https:// doi.org/10.1163/9789004379282_006. 
Morbidelli, P., Tucci, P., Imperatori, C., Polvorinos, A., Preite Martinez, M., Azzaro, E., Hernandez, M.J., 2007. Roman quarries of the Iberian Peninsula: “Anasol” and “Anasol”-type. Eur. J. Mineral. 19, 125-135. https://doi.org/10.1127/0935-1221/ 2007/0019-0125.

Origlia, F., Gliozzo, E., Meccheri, M., Spangenberg, J.E., Memmi, I.I., Papi, E., 2011. Mineralogical, petrographic and geochemical characterisation of white and coloured Iberian marbles in the context of the provenancing of some artefacts from Thamusida (Kenitra, Morocco). Eur. J. Mineral. 23, 857-869. https://doi.org/10.1127/09351221/2007/0019-0125.

Origlia, F., Gliozzo, E., Gandin, A., Meccheri, M., Spangenberg, J.E., Memmi, I.T., 2012. Marbles and carbonate rocks from central Morocco: A petrographic, mineralogical and geochemical study. Environ. Earth Sci. 66, 209-222. https://doi.org/10.1007/ s12665-011-1224-4.

Pharr, C., 1961. Ancient Roman Statutes, Austin.

Poupaki, E. 2017. Ancient Koan marble quarries and the distribution of Koan marble in antiquity: Results of the recent archaeological research, in [Greek] To $\alpha \rho \chi \alpha 10 \lambda o \gamma ı \kappa^{\prime}$

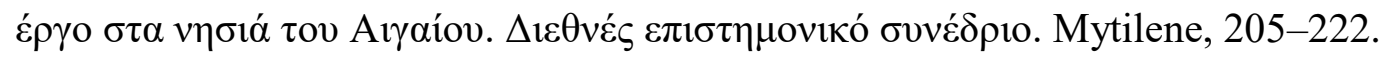
Ramage, M.H., Tykot, R.H., 2011. Appendix 4: Geological analysis of Lydian building stones and their quarry sources, in C. Ratté, Lydian Architecture: Ashlar Masonry Structures at Sardis, 127-132, Cambridge, MA.

Robert, L., 1936. Collection Froehner: I. Inscriptions grecques. Éditions des Bibliothèques nationales, Paris.

Rebillard, E., 2009. The Care of the Dead in Late Antiquity, Ithaca.

Rumble III, D., Wang, Q., Zhang, R., 2000. Stable isotope geochemistry of marbles from the coesite UHP terrains of Dabieshan and Sulu. China. Lithos 52, 79-95. https://doi. org/10.1016/S0024-4937(99)00085-7.

Russell, B., 2013. The Economics of the Roman Stone Trade, Oxford.

Sekedat, B.M., 2016. X-Ray Fluorescence and stable isotope analysis of marble in Central Lydia Western Turkey. Oxford J. Archaeol. 35, 369-388. https://doi.org/10.1111/ ojoa. 12094. 
Sharp, Z., 2017. Principles of Stable Isotope Geochemistry, second ed. https://digitalrepository. unm.edu/unm_oer/1/.

Sherwin-White, S., 1978. Ancient Cos: An Historical Study from the Dorian Settlement to the Imperial Period, Göttingen.

Tsalampouni, E., 2001. The Nazareth Inscription: A controversial piece of Palestinian epigraphy (1930-1999). Tekmeria 6, 70-122. https://doi.org/10.12681/tekmeria. 170.

Tzaferis, V., Bagatti, B., 1993. Nazareth In: E. Stern, et al. (Eds.), The New Encyclopedia of Archaeological Excavations in the Holy Land, vol. 3., 1103-1106, Carta.

Veizer, Ján, Ala, Davin, Azmy, Karem, Bruckschen, Peter, Buhl, Dieter, Bruhn, Frank, Carden, Giles A.F., Diener, Andreas, Ebneth, Stefan, Godderis, Yves, Jasper, Torsten, Korte, Christoph, Pawellek, Frank, Podlaha, Olaf G., Strauss, Harald, 1999. 87Sr/86Sr, $\delta 13 \mathrm{C}$ and $\delta 18 \mathrm{O}$ evolution of Phanerozoic seawater. Chem. Geol. 161 (1-3), 59-88. https://doi.org/10.1016/S0009-2541(99)00081-9.

Ward-Perkins, J.B., 1980. Nicomedia and the marble trade. Papers Br. Sch. Rome 48, 23-69. https://doi.org/10.1017/S0068246200008357.

Wenner, D.B., Havert, S., Clark, A., 1988. Variations in stable isotopic compositions of marble: An assessment of causes. In: Herz, N., Waelkens, M. (Eds.), Classical Marble: Geochemistry, Technology, Trade, Series E: Applied Sciences, Dordrecht, pp. 325-338. https://doi.org/10.1007/978-94-015-7795-3_35. 


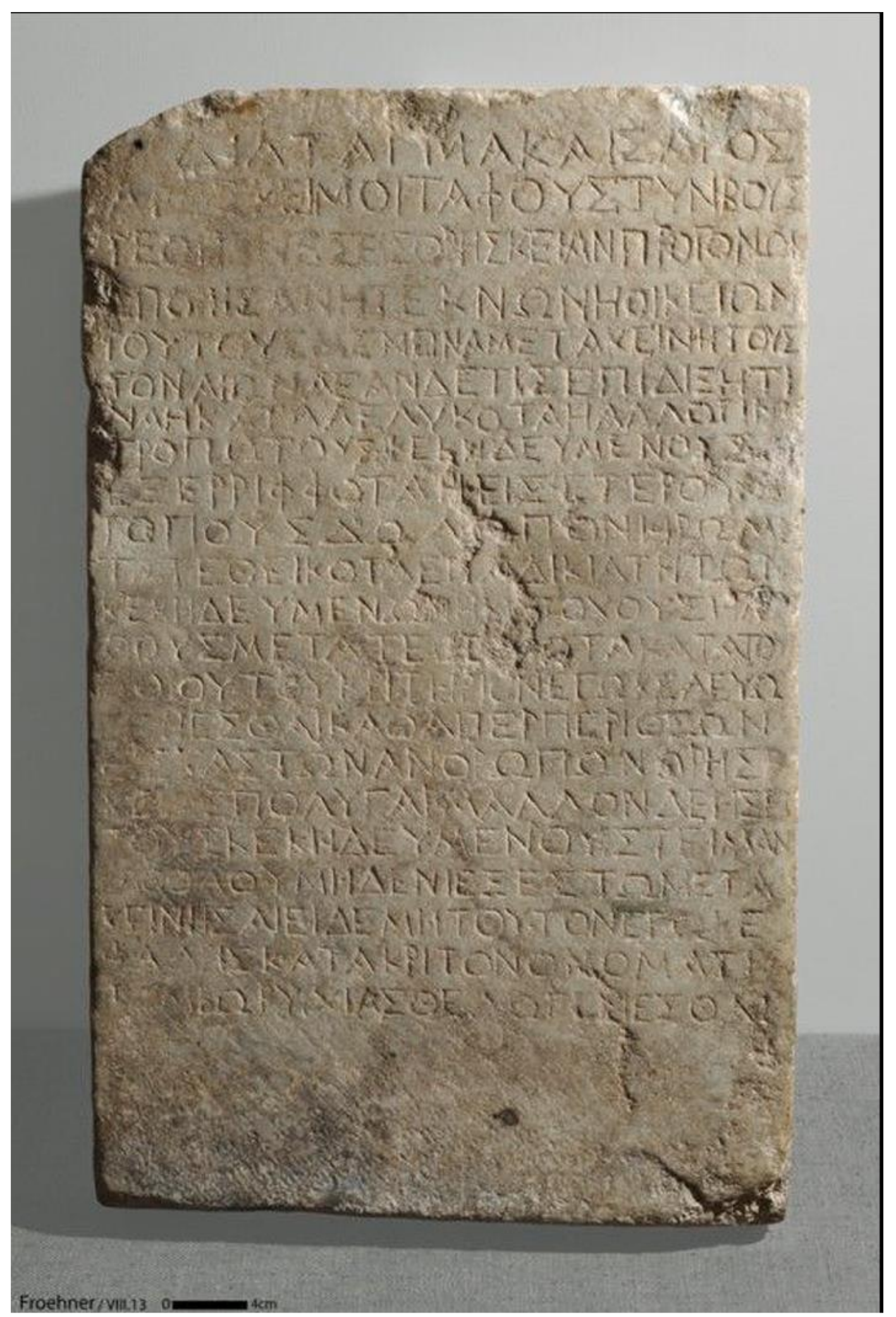

Fig. 1. The Nazareth Inscription, Bibliothèque nationale in Paris, France. (http://medaillesetantiques.bnf.fr/ws/catalogue/app/collection/record/ark:/ 12148/c33gb6sb). 


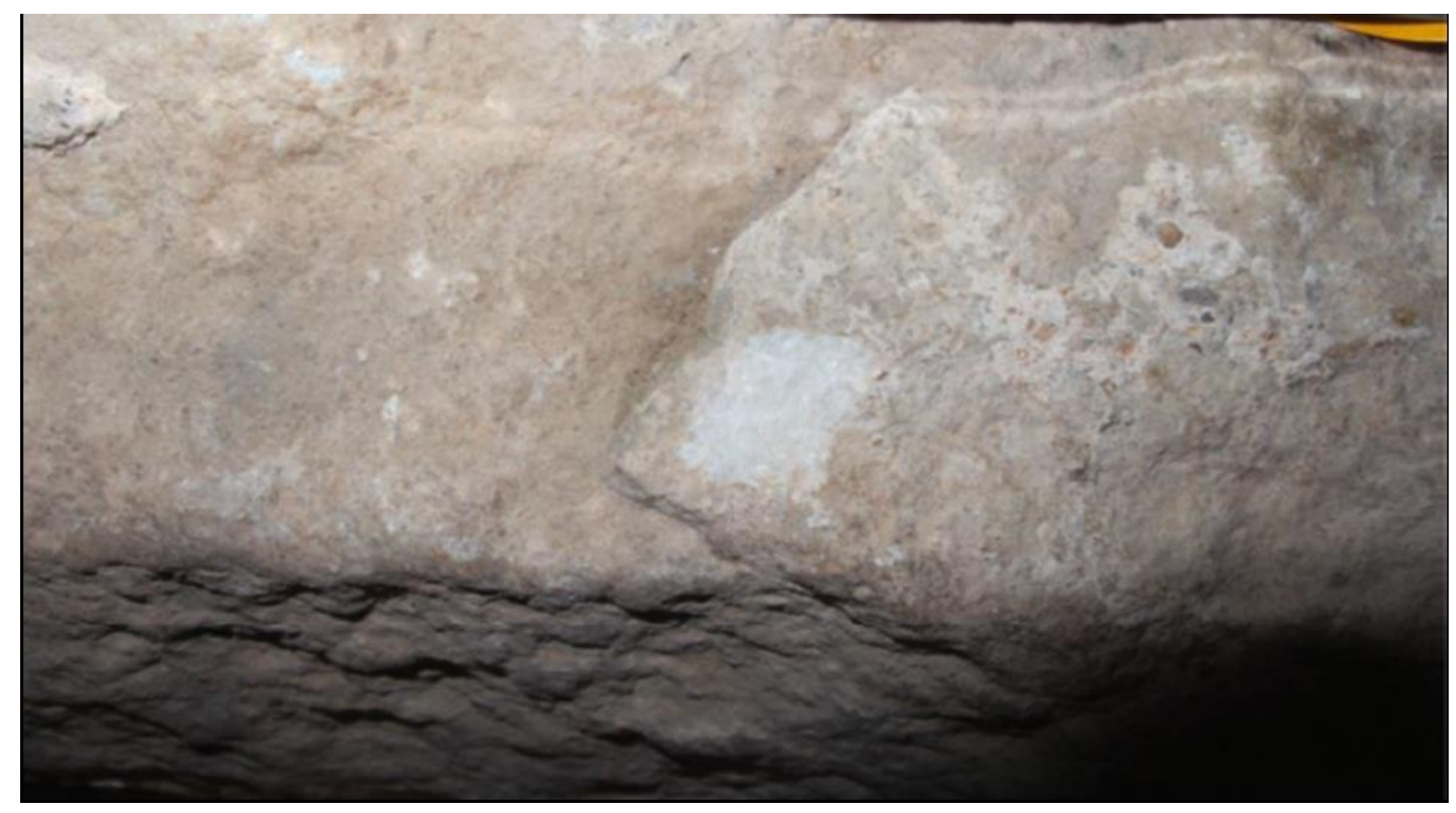

Fig. 2. Cleaned surface where samples were taken from the inscription for elemental and stable isotope analysis. 

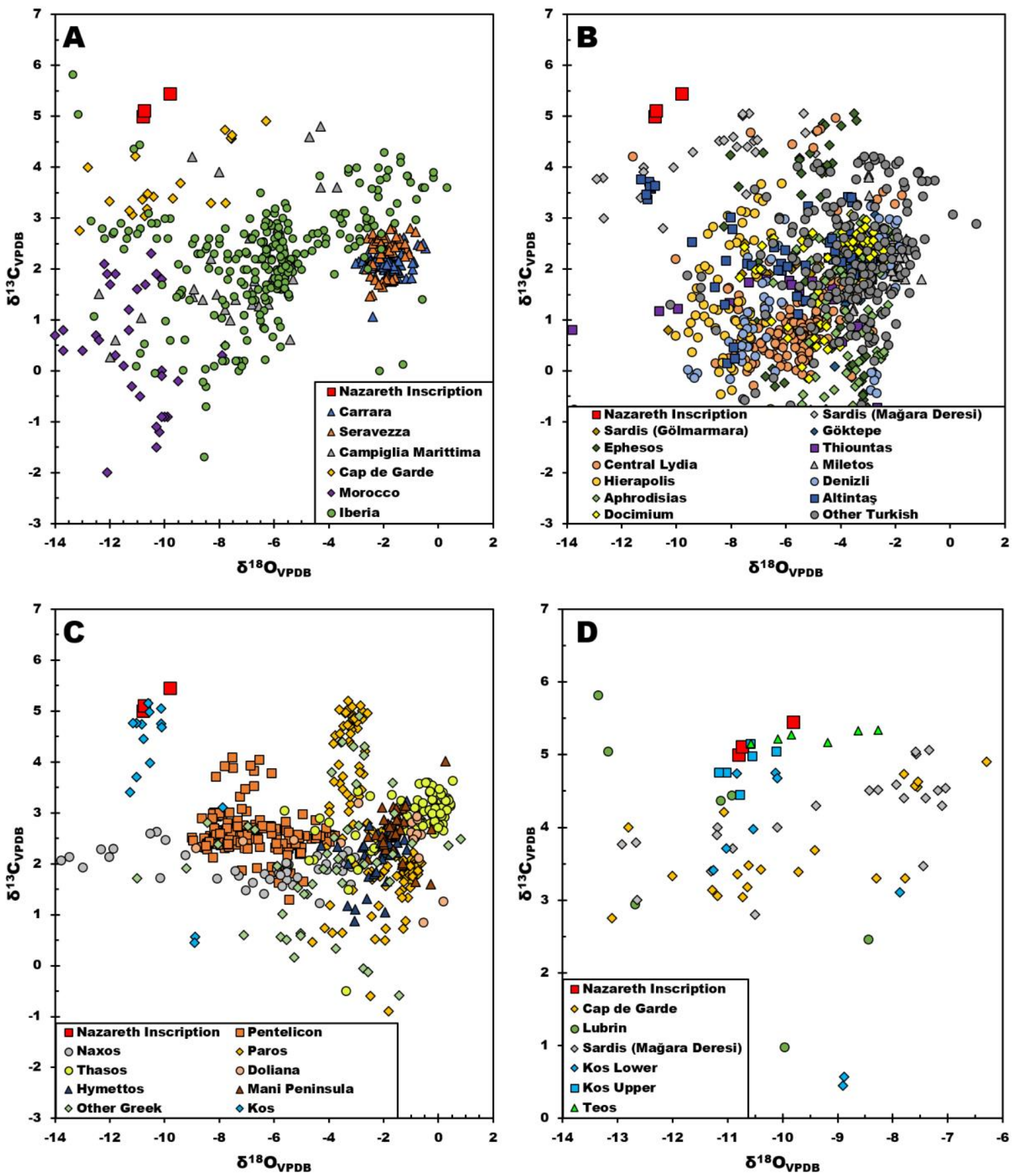

Figure 3. Stable isotopic ratios of the Nazareth inscription compared to published values from various white marbles along the Mediterranean. (A) Marbles from Italy (Attanasio et al., 2006; Cavari et al., 2012; Franzini et al., 2010) , Iberia (Lapuente et al., 2000; Morbidelli et al., 2007; Origlia et al., 2011) and North Africa (Antonelli et al., 2009; Origlia et al., 2012). (B) Anatolian/Turkish marbles (Attanasio et al., 2006; Attanasio et al., 2008; Attanasio et al., 2009; Brilli et al., 2015; Cahill and Lazzarini, 2014; Capedri et al., 2004; De Paepe et al., 2004; De Paepe et al., 2006; Ramage and Tykot, 2011; Sekedat, 2016). (C) Greek and Greek Aegean marbles (Attanasio et al., 2006; Lazzarini and Malacrino, 2010; Capedri et al., 2004; Lazzarini and Cancelliere, 2000). (D) The closest matches of literature values for the Nazareth Inscription: Cap de Garde, Algeria (Antonelli et al., 2009), Lubrin, Spain (Lapuente et al., 2000), Mağara Deresi, Sardis, Turkey (Cahill and Lazzarini, 2014; Ramage and Tykot, 2011), Kos upper and lower quarries (Lazzarini and Malacrino, 2010), dark marble from Teos, Turkey (Attanasio et al., 2017). 



\begin{tabular}{|c|c|c|c|c|}
\hline \multicolumn{2}{|c|}{ Elements (ppm) } & \multicolumn{3}{|c|}{ Stable Isotopes } \\
\hline $\mathrm{Ca}$ & 440200 & & $\delta^{13} C_{\text {VPDB }}$ & $\delta^{18} \mathrm{O}_{\mathrm{VPDB}}$ \\
\hline $\mathrm{Mg}$ & 6258 & & 5.00 & -10.80 \\
\hline \multirow[t]{3}{*}{$\mathrm{Sr}$} & 227 & & 5.45 & -9.81 \\
\hline & & & 5.11 & -10.74 \\
\hline & & Average: & 5.19 & -10.45 \\
\hline
\end{tabular}

Table 1. Composition of the marble from the Nazareth Inscription. 